\title{
Sprayer Type and Pruning Affect the Incidence of Blueberry Fruit Rots
}

\author{
Eric Hanson ${ }^{1}$ and Jim Hancock ${ }^{2}$ \\ Department of Horticulture, Michigan State University, East Lansing, \\ MI 48824-1325
}

\author{
Donald C. Ramsdell ${ }^{3}$ and Annemiek Schilder ${ }^{4}$ \\ Department of Botany and Plant Pathology, Michigan State University, East \\ Lansing, MI 48824-1325
}

\author{
Gary VanEe ${ }^{5}$ and Richard Ledebuhr ${ }^{6}$ \\ Department of Agricultural Engineering, Michigan State University, East \\ Lansing, MI 48824-1325 \\ Additional index words. Alternaria sp., anthracnose, Botrytis cinerea, Colletotrichum
acutatum, Rizopus sp., Vaccinium corymbosum
}

\begin{abstract}
Highbush blueberries (Vaccinium corymbosum L.) in Michigan are treated annually with fungicides to control fruit rots caused by Colletotrichum acutatum J.H. Simmonds, Alternaria sp., and Botrytis cinerea Pers.:Fr. Control with recommended fungicide programs is often inadequate. The goal of this study was to compare the effects of two spray treatments and three levels of pruning severity on fruit rot levels in mature 'Jersey' bushes. Two spray treatments were tested for 3 years: 1) recommended fungicide rates applied with a conventional airblast sprayer; 2) $67 \%$ of recommended fungicide rates applied with a multifan/nozzle, above-row sprayer. Pruning treatments included light and heavy pruning (compared for 1 year), and light, moderate, and heavy pruning (compared for 3 years). Fruit rot incidence was determined after incubating individual fruit at $100 \%$ relative humidity and $21^{\circ} \mathrm{C}$ for 7 to 11 days, and after exposing $0.24-\mathrm{L}$ plastic clamshell containers of fruit to simulated commercial handling. The above-row sprayer provided fruit rot control at least equivalent to the airblast sprayer even though less chemical was applied. Anthracnose rot in berries from the top of the bush canopy were reduced by pruning, but those in the bottom of the bush, and levels of other diseases were not consistently affected. Pruning also reduced yields, although the study was too short in duration to determine the long-term impact on production.
\end{abstract}

Several fruit-rotting fungi cause significant losses in highbush blueberries. In Michigan, the most serious fruit diseases are caused by Colletotrichum acutatum (anthracnose fruit rot or ripe rot), Alternaria sp. (Alternaria rot), and, to a lesser extent, Botrytis cinerea (Ramsdell, 1989; Schilder, unpublished data). Anthracnose infections may occur anytime between bloom and harvest (Hartung et al., 1981), whereas most Alternaria infections

\footnotetext{
Received for publication 19 Apr. 1999. Accepted for publication 4 Sept. 1999. Acknowledgment is made to the Michigan Agricultural Experiment Station and MBG Marketing, Grand Junction, Mich., for support of this work. The authors wish to thank Steven Paul for his cooperation and assistance during this project. The cost of publishing this paper was defrayed in part by the payment of page charges. Under postal regulations, this paper therefore must be hereby marked advertisement solely to indicate this fact.

${ }^{1}$ Professor, Dept. of Horticulture; to whom reprint requests should be addressed (e-mail: hansone@msu.edu).

${ }^{2}$ Professor, Dept. of Horticulture.

${ }^{3}$ Professor Emeritus, Dept. of Botany and Plant Pathology.

${ }^{4}$ Assistant Professor, Dept. of Botany and Plant Pathology.

${ }^{5}$ Professor, Dept. of Agricultural Engineering.

${ }^{6}$ Specialist, Dept. of Agricultural Engineering.
}

appear to occur later in the season (Bristow and Windom, 1998). Colletotrichumacutatum, Alternaria sp., and Botrytis sp. can also infect fruit after harvest (Ceponis and Cappellini, 1987; Cline, 1996). Fungicides applied to control fruit rots account for over half of the crop protection chemicals applied annually to Michigan blueberries (U.S. Dept. of Agriculture, National Agricultural Statistics Service, 1998). Even when fungicide recommendations are followed, losses from fruit rots can be significant, emphasizing the need for improved control methods.

In Michigan, fungicides are applied to commercial blueberries with fixed-wing aircraft and various ground equipment. The primary fungicide used to control blueberry fruit rots is captan ( $\mathrm{N}$-Trichloromethylthio4-cyclohexene-1,2-dicarboximide), a nonsystemic protectant that needs to be applied uniformly throughout the canopy for greatest benefit. Application equipment characteristics and operation can affect fungicide efficacy by altering deposition patterns. Equipment that can treat large areas quickly (high field capacity) provides the flexibility necessary to treat large areas when conditions are optimal.

Airblast sprayers that propel spray up and through bushes are used by many Michigan growers. Cannon sprayers that project spray across the tops of several blueberry rows are also popular because the field capacity is high, and, since fewer passes through the field are required, the potential for mechanical damage to developing fruit is minimized. An aboverow sprayer recently developed by researchers at Michigan State Univ. (MSU) shows promise because multiple fans and atomizers provide uniform droplet size and the machine has a relatively high field capacity. Canopy management by pruning may also aid in the control of fruit rots, since fruit-rotting pathogens are known to overwinter in infected twigs, and need high relative humidity and free moisture for infection and sporulation (Caruso and Ramsdell, 1995). The goal of this project, therefore, was to determine if fungicide rates could be reduced by utilizing the above-row sprayer or by modifying the bush architecture through pruning.

\section{Materials and Methods}

The study site was a 40-year-old commercial planting of 'Jersey' bushes in Muskegon, Mich. Bushes were $1.2 \mathrm{~m}$ apart in north-tosouth oriented rows spaced $3 \mathrm{~m}$ apart (2690 bushes/ha). Two spray treatments were imposed in 1995, 1996, and 1997: 1) recommended fungicide rates applied with an conventional airblast sprayer, and 2) $67 \%$ of the recommended fungicide rates applied with an experimental above-row sprayer. Except for the difference in fungicide rates, sprays were applied by the grower according to commercial recommendations for Michigan blueberries (Johnson et al., 1995) (Table 1). The airblast sprayer was an Agtec (Ag-Chem, Minnetonka, Minn.) three-point hitch mounted unit that delivered $187 \mathrm{~L} \cdot \mathrm{ha}^{-1}$ spray volume at a nozzle pressure of $1.0 \mathrm{kPa}$. The sprayer was driven over alternate row middles at $1.5 \mathrm{~m} \cdot \mathrm{s}^{-1}$, and had an estimated field capacity of $3.2 \mathrm{ha} \cdot \mathrm{h}^{-1}$. The above-row sprayer was constructed by agricultural engineers at MSU, and was similar to machines marketed by Ledebuhr Industries (Bath, Mich.). The sprayer boom covered four rows (two nozzle-fan units per row), and delivered a spray volume of $93 \mathrm{~L} \cdot \mathrm{ha}^{-1}$ at a nozzle pressure of $1.2 \mathrm{kPa}$. The above-row sprayer was driven through every fourth row middle at $1.52 \mathrm{~m} \cdot \mathrm{s}^{-1}$, giving a field capacity of $6.7 \mathrm{ha} \cdot \mathrm{h}^{-1}$. The nozzle/fan assemblies were positioned $\approx 1 \mathrm{~m}$ apart along the boom, and were oriented at roughly 8 o'clock and 4 o'clock positions $\approx 1 \mathrm{~m}$ above the plants. Both fans were angled $\approx 20^{\circ}$ toward the center of the row, the front fan being angled forward, the back one rearward. The sprayer plots were five rows wide, 135 bushes long, and replicated twice. In 1998, the entire study area was treated with an airblast sprayer at recommended fungicide rates (Table 1).

Three pruning severity treatments (light, moderate, heavy) were assigned to plots in Mar. 1995. At that time, 20\% of the largest canes were removed from bushes in the heavy pruning plots, and other plots were not pruned. Thus, only two pruning severities were compared in 1995. In Mar. 1996, 20\% of the largest 
Table 1. Fungicide ${ }^{\mathrm{z}}$ application times and rates for the airblast and above-row spray treatments applied to 'Jersey' blueberries in Muskegon, Mich.

\begin{tabular}{|c|c|c|c|c|}
\hline Growth stage & 1995 & 1996 & 1997 & 1998 \\
\hline Green tip & Triforine; $0.015,0.01^{y}$ & & $\begin{array}{l}\text { Benomyl; 0.23, } 0.15 \\
\text { Captan; } 0.9,0.6\end{array}$ & Chlorothalonil; 1.68 \\
\hline Pink bud & $\begin{array}{l}\text { Benomyl; } 0.23,0.15 \\
\text { Captan; 0.9, 0.6 } \\
\text { Triforine; } 0.015,0.01\end{array}$ & Captan; 0.9, 0.6 & $\begin{array}{l}\text { Benomyl; 0.23, } 0.15 \\
\text { Captan; 0.9, } 0.6\end{array}$ & Chlorothalonil; 1.68 \\
\hline Bloom & $\begin{array}{l}\text { Benomyl; } 0.23,0.15 \\
\text { Captan; } 0.9,0.6\end{array}$ & $\begin{array}{l}\text { Captan; } 0.9,0.6 \\
\text { Triforine; } 0.01,0.007\end{array}$ & $\begin{array}{l}\text { Benomyl; } 0.23,0.15 \\
\text { Captan; } 0.9,0.6\end{array}$ & Ziram; 1.68 \\
\hline Petal fall & Captan; 0.9, 0.6 & $\begin{array}{l}\text { Benomyl; 0.23, } 0.15 \\
\text { Captan; 0.9, } 0.6\end{array}$ & & Fosetyl-Al; 2.24 \\
\hline
\end{tabular}

${ }^{2}$ Commercial products used: benomyl [1-(butylcarbamoyl)-2-benzinidazolecarbamate] (Benlate $₫ 50$ WP, DuPont Inc.); captan (Captec $₫ 4$ FL, Micro- Flow Co); chlorothalonil (tetrachloroisophthalonitrile) (Bravo ${ }^{\circledR}$ Weather Stick, Zeneca); fosetyl-Al [aluminum tris ( $O$-ethyl phosphonate)] (Aliette ${ }^{\circledR}$ WDG, Rhone-Poulenc); triforine $\left\{N, N^{\prime}\right.$-[1,4-piperazinediyl-bis(2,2,2-trichloroethylidene)]-bis-[formamide] $\}$ (Funginex ${ }^{\circledR} 18.2$ EC, Ciba-Geigy); ziram (zinc dimethyldithiocarbamate) (Ziram ${ }^{\circledR} 76 \mathrm{DF}$, Elf Atochem).

${ }^{\mathrm{y}} \mathrm{Rates}\left(\mathrm{kg} \mathrm{ha}^{-1}\right.$ a.i.) for the airblast spray treatment are listed first, and for the above row treatment second. In 1998, all plots were treated with an airblast sprayer at the same rate.

canes were removed from the moderately pruned plots, and an additional $20 \%$ were removed from the heavily pruned ones to give three pruning severities. In Apr. 1997, all plots were pruned similarly, so that the relative canopy differences established in 1996 were maintained. In Winter 1998, a commercial pruning crew inadvertently pruned the entire study area. Later that winter, we lightly pruned the moderate pruning plots by removing two or three canes per bush, and pruned the heavy pruning plots more severely by removing five or six canes, in order to reestablish relative differences in canopy densities. Pruning plots were five rows wide, 15 bushes long, and replicated three times within each spray treatment plot (a total of 12 replications).

Yield data were collected by harvesting the middle row of each plot with an over-the-row mechanical harvester on two dates in 199598, and weighing the fruit. Subsamples of 100-200 berries were counted and weighed to calculate average berry weight. Cane diameter $<20 \mathrm{~cm}$ above the crown was recorded on two bushes per plot in May 1996-98, in order to describe relative differences in canopy densities.

Fruit samples for rot evaluations were picked by hand from the middle row of each plot before each machine harvest. Separate samples were collected from the top periphery and the bottom interior of bushes. The presence of fruit-rotting fungi was assessed by incubation tests (1995-98) and commercial handling simulations $(1997,1998)$. The incubation tests consisted of arranging separated fruit equidistant from one another on a $0.5-\mathrm{cm}$ mesh screen in plastic food-grade tubs. The tubs were filled with water below the screen level, covered with plastic film to maintain $100 \%$ relative humidity, and held at $21^{\circ} \mathrm{C}$. In 1995, 1996, and 1997, samples of 50 berries were incubated for $7 \mathrm{~d}$. In 1998, 100-berry samples were incubated for $11 \mathrm{~d}$. After the incubation period, fruit were examined for the presence of Alternaria, Colletotrichum, and Botrytis. The presence of Rhizopus sp. was also evaluated in 1995 only. Fungi were identified by sporulation characteristics, which required microscopic examination in some cases.

Commercial handling was simulated by placing berries in $0.24-\mathrm{L}$ plastic clamshell containers, holding the containers for varying lengths of time at 2 and $19^{\circ} \mathrm{C}$, then inspecting the berries for the presence of fungal decay. Fruit samples were collected before the first and second harvests in 1997, and separate sets of samples were assessed after either $1 \mathrm{~d}$ at 2 ${ }^{\circ} \mathrm{C}$ followed by $3 \mathrm{~d}$ at $19{ }^{\circ} \mathrm{C}$, or after $7 \mathrm{~d}$ at $2{ }^{\circ} \mathrm{C}$ followed by $3 \mathrm{~d}$ at $19^{\circ} \mathrm{C}$. In 1998 , samples were collected only before the second harvest

Table 2. Effect of pruning on the percentage of canes with different base diameters (cm) in 'Jersey' bushes in Muskegon, Mich.

\begin{tabular}{|c|c|c|c|c|c|c|}
\hline \multirow{2}{*}{$\begin{array}{l}\text { Pruning } \\
\text { treatment }\end{array}$} & \multirow{2}{*}{$\begin{array}{c}\text { Total } \\
\text { canes/bush }\end{array}$} & \multicolumn{5}{|c|}{ Percentage of canes in size categories } \\
\hline & & $<0.6$ & $0.6-1.3$ & $1.4-1.9$ & $2.0-2.5$ & $>2.5$ \\
\hline \multicolumn{7}{|c|}{ May 1996} \\
\hline Light & $41.9 \mathrm{a}^{\mathrm{z}}$ & $36 \mathrm{a}$ & 41 & $14 \mathrm{a}$ & 7 & 1 \\
\hline Moderate & $37.4 \mathrm{ab}$ & $46 \mathrm{~b}$ & 40 & $11 \mathrm{ab}$ & 3 & 0 \\
\hline Heavy & $34.9 \mathrm{~b}$ & $42 \mathrm{ab}$ & 43 & $9 \mathrm{~b}$ & 5 & 1 \\
\hline \multicolumn{7}{|c|}{ May 1997} \\
\hline Light & 58.5 & $17 \mathrm{a}$ & 58 & $14 \mathrm{a}$ & 9 a & 2 \\
\hline Moderate & 58.8 & $26 \mathrm{~b}$ & 58 & $12 \mathrm{ab}$ & $4 \mathrm{~b}$ & 0 \\
\hline Heavy & 70.0 & $25 \mathrm{~b}$ & 65 & $8 \mathrm{~b}$ & $1 \mathrm{c}$ & 0 \\
\hline \multicolumn{7}{|c|}{ May 1998} \\
\hline Light & 20.1 & 4 & 47 & 29 & $17 \mathrm{a}$ & 2 \\
\hline Moderate & 21.3 & 9 & 56 & 24 & $10 \mathrm{ab}$ & 1 \\
\hline Heavy & 19.4 & 8 & 62 & 24 & $6 \mathrm{~b}$ & 0 \\
\hline
\end{tabular}

${ }^{\mathrm{z}}$ Mean separation within columns and years by LSD, $P \leq 0.05$. If no letters, the F-test was nonsignificant. and were assessed after either $5 \mathrm{~d}$ at $2{ }^{\circ} \mathrm{C}$ followed by $2 \mathrm{~d}$ at $19^{\circ} \mathrm{C}$, or after $12 \mathrm{~d}$ at $2^{\circ} \mathrm{C}$ followed by $2 \mathrm{~d}$ at $19^{\circ} \mathrm{C}$. To assess rot levels in the commercial simulation samples, berries were placed on trays and counted, and the number exhibiting sporulation typical of $A l$ ternaria, Colletotrichum, and Botrytis sp. was recorded.

All data were analyzed by analysis of variance as a split-block design using M-STAT (Dept. of Crop and Soil Sciences, Michigan State Univ., East Lansing) or SAS (SAS Institute, Cary, N.C.) statistical packages. The main plots were the two sprayer treatments, and the sub-plots consisted of the three pruning treatments. Fruit rot data from each year, harvest, and position in the canopy were analyzed separately. Percentage data were arcsin-transformed prior to analysis.

\section{Results and Discussion}

Cane numbers and yields. Heavy pruning decreased the total number of canes in 1996, but not in 1997 or 1998 (Table 2). Pruning also tended to increase the percentage of canes in the smaller-size categories, and reduce the percentages in the intermediate- and largesize categories. Pruning significantly reduced yields in 1996 and 1997, but not in 1995 or 1998 (Table 3). Berry weight was not affected by pruning (data not shown), with the exception of the first harvest in 1996, when the average berry weight was significantly lower in moderately pruned $(1.27 \mathrm{~g})$ than in heavily pruned plots $(1.32 \mathrm{~g})$, although neither was significantly different from the light pruning treatment $(1.3 \mathrm{~g})$. Across all years and treatments, berry weight was greater in the first

Table 3. Effect of pruning treatments on yield of 'Jersey' blueberries in Muskegon, Mich., 1995 to 1998.

\begin{tabular}{lcccc}
\hline \hline Pruning & \multicolumn{4}{c}{ Yield (kg/bush) } \\
\cline { 2 - 5 } treatment & 1995 & 1996 & 1997 & 1998 \\
\hline Light & 2.8 & $1.0 \mathrm{a}^{\mathrm{z}}$ & $2.5 \mathrm{a}$ & 1.8 \\
Moderate & --- & $0.7 \mathrm{~b}$ & $1.8 \mathrm{~b}$ & 1.6 \\
Heavy & 2.5 & $0.9 \mathrm{ab}$ & $1.6 \mathrm{~b}$ & 1.7 \\
\hline \multicolumn{4}{l}{ Mean separation within columns and years by LSD, }
\end{tabular}

$P \leq 0.05$. If no letters, the F-test was nonsignificant 
harvest $(1.29 \mathrm{~g})$ than in the second $(0.63 \mathrm{~g})$. Yields and berry weights were not significantly affected by the spray treatments or the interaction of the spray and pruning treatments (data not shown).

The inadvertent pruning by the grower's crew in Winter 1998 reduced total cane numbers from the previous year, and greatly reduced the number of small-diameter canes. Our selective pruning later in 1998 reestablished some treatment differences. Although all plots contained the same number of canes, the lightly pruned plots contained greater percentages in the large-size categories. The optimum number and age distribution of canes in 'Jersey' bushes has not been clearly defined; however, based on commercial standards, the lightly pruned plots were considered in need of pruning by the 1996 and 1997 seasons, whereas the canopy densities in the moderate and heavily pruned plots were considered acceptable. In 1998 , all bushes were properly pruned by commercial standards.

The reduction in 1996 and 1997 yields due to pruning was expected because large, productive canes were removed. In 1996, bushes in the moderately and heavily pruned plots contained $\approx 10 \%$ and $20 \%$ fewer canes, respectively, than those in the lightly pruned plots, and these differences were all in the larger size categories $(>1.3 \mathrm{~cm})$. Over time, bushes would be expected to respond to moderate and heavy pruning by producing more vigorous, productive canes in the intermediate-size categories, which would compensate for heavier pruning. By 1996 and 1997, moderate and heavy pruning had stimulated the growth of more canes in the smallest-size class. However, the study was not conducted long enough for these canes to become productive. Overall yields in 1996 were low because of reduced flower bud production and winter injury. Although pruning often increases berry weight in 'Jersey' (Siefker and Hancock, 1987), average berry weight was not consistently affected by pruning in this study. Overall yields during the study were only low to moderate compared with those in Siefker and Hancock's (1987) study, so berry weight and yield were probably limited by heavy cropping stress.

Fruit rot. Fruit fungal infections were assessed by incubating fruit from two harvests in 1995, 1996, and 1997, and from one harvest in 1998, and by simulating short- and long-term commercial handling conditions with fruit from two harvests in 1997, and one harvest in 1998. Anthracnose was the primary fruit rot in 1995 , 1996, and 1998, whereas Botrytis rot was most prevalent in 1997 (Fig. 1). However, levels of each pathogen varied considerably between years and between harvests in the same year (Fig. 1). Anthracnose rot was consistently higher in fruit from the bottoms than from the tops of bushes, when compared by a paired $t$ test. Means from incubation tests were $22.8 \%$ and $34.4 \%$ for the top and bottom fruit, respectively $(P \leq 0.001)$, and means for simulated storage tests were $3.7 \%$ and $7.6 \%$ for top and bottom fruit $(P \leq 0.01)$. Botrytis and Alternaria rot levels did not differ significantly between the top and bottom of the bush.

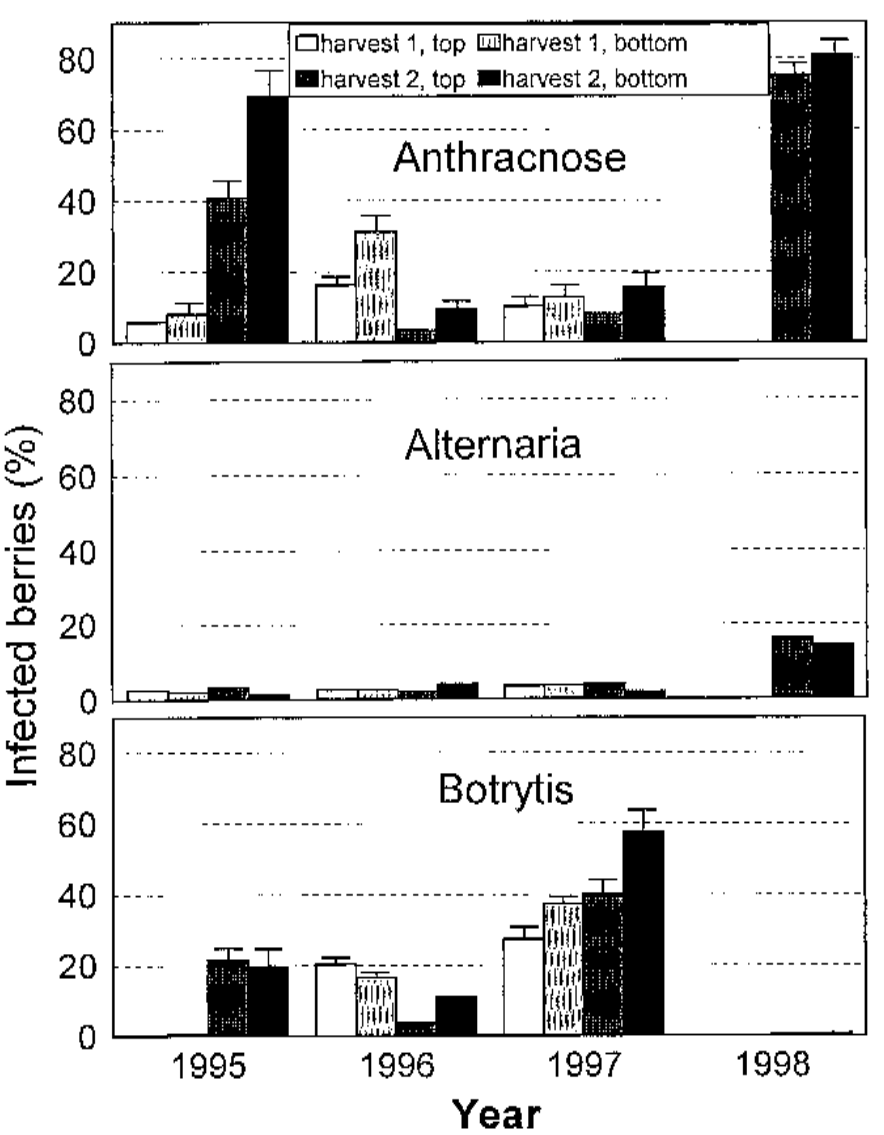

Fig. 1. Percentage of 'Jersey' blueberries with anthracnose, Alternaria, and Botrytis rot following incubation tests at $100 \%$ relative humidity and $21{ }^{\circ} \mathrm{C}$ for $7 \mathrm{~d}(1995-97)$ or $11 \mathrm{~d}$ (1998). Error bars represent one SE of the mean.

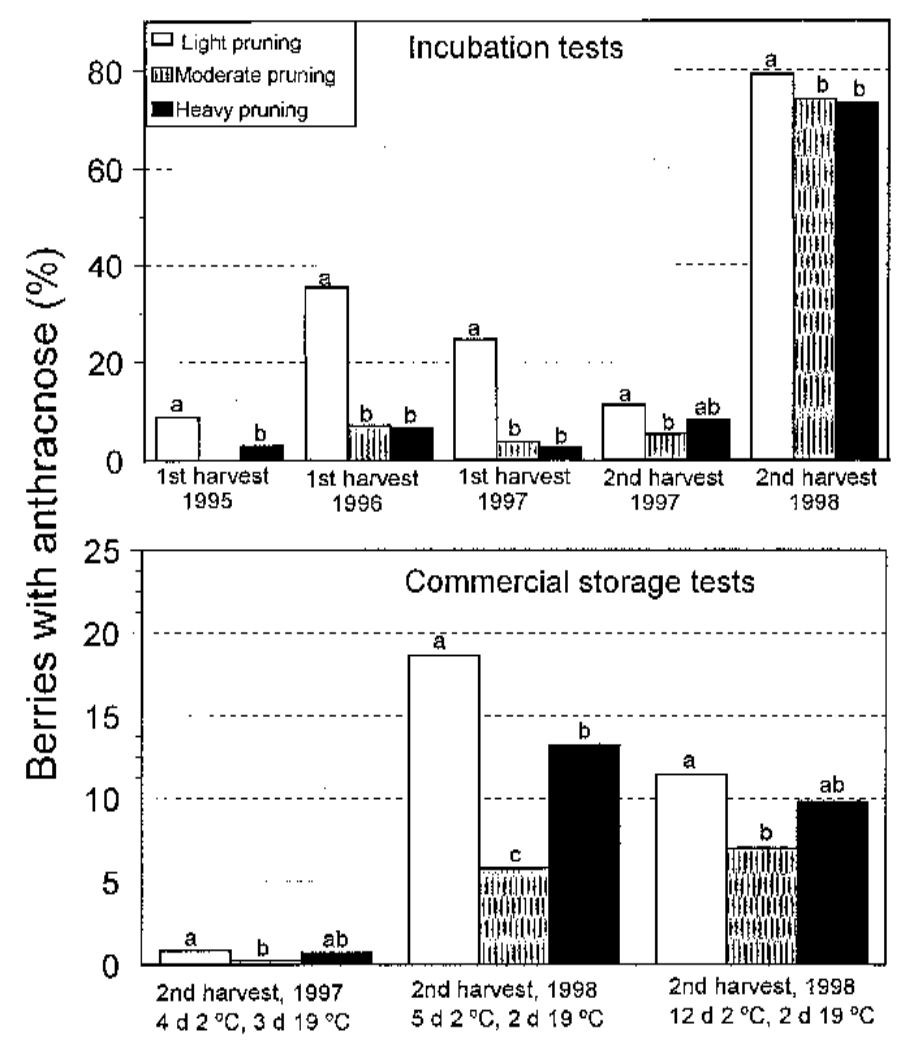

Fig. 2. Effect of pruning on anthracnose levels in 'Jersey' blueberries from the tops of bushes. Mean separation within harvests and years by LSD, $P \leq 0.05$. 
Moderate or heavy pruning significantly reduced anthracnose levels in berries from the tops of bushes in five of seven incubation tests and three of six simulated commercial storage tests (Fig. 2). Data from tests where pruning did not significantly affect anthracnose levels are not shown. In the commercial tests, rot levels were lower in moderately pruned than lightly pruned plots in each case, and, in one case, moderate pruning also resulted in lower rot levels than did heavy pruning (Fig. 2).

Pruning could potentially reduce fruit rots by removing diseased wood that is a source of inoculum, or by opening the canopy to hasten drying and/or improve spray penetration (Cooley et al., 1997). Pruning probably reduced anthracnose rot by removing infected wood (Ramsdell, 1992), which is the primary source of anthracnose inoculum (Hartung et al., 1981). If the benefits of pruning were associated with enhanced drying or improved spray penetration, pruning would also be expected to reduce the levels of Alternaria or Botrytis rot, which was not the case in this study.

Why pruning often reduced anthracnose levels in the top but not the bottom of bushes is not clear. Perhaps this observation reflects spacial differences in anthracnose inoculum levels. Fruit in the bottom interior of the canopy had higher levels of anthracnose and may have been exposed to higher spore numbers if those discharged from infected tissue in the top of the canopy migrated downward. Spore numbers may have been so high in the bottom of the canopy that modest reductions due to pruning were not sufficient to reduce fruit infections. Pruning also opens the canopy and should reduce drying times and canopy moisture levels. Perhaps moisture levels in the bottom of the canopy were not reduced sufficiently by pruning to affect infection levels.

The spray treatments occasionally affected levels of specific pathogens in specific tests (Table 4), but overall, the spray treatments had similar effects on rot levels. Levels of each fruit rot in berries from both positions in the bush were compared 17 times over different years, harvests, and evaluation tests. Compared with the airblast spray treatment, the above-row treatment resulted in lower anthracnose levels in berries from the tops (two of 17 instances) and bottom of bushes (one of 17 instances), lower Alternaria rot in the bottom of the bush in one instance, and higher Botrytis rot in the top of the bush in one instance. Although Rhizopus was only evaluated in 1995, infection levels in the bottoms of bushes were significantly higher with the use of the airblast ( $9.4 \%$ of berries) than with the above-row sprayer $(1.6 \%)$. The above-row sprayer resulted in lower rot levels than the airblast sprayer in five of the six instances when the spray treatment significantly affected rot levels.

Interpreting the spray treatment effects is complicated by the fact that both the sprayer and the fungicide rate were varied. Additional treatments to compare sprayers at the same

Table 4. Instances of significant spray treatment effects on fruit rot levels (percentages of berries infected) in the top and bottom of 'Jersey' blueberry bushes in Muskegon, Mich. Levels of each rot organism in berries from the top and bottom positions were compared 17 times over years and harvests using different evaluation methods. Data from nonsignificant comparisons not reported.

\begin{tabular}{|c|c|c|c|c|c|}
\hline \multirow[b]{2}{*}{ Year } & \multirow[b]{2}{*}{ Test } & \multirow[b]{2}{*}{ Harvest } & \multirow[b]{2}{*}{ Location } & \multicolumn{2}{|c|}{ Berries infected $(\%)$} \\
\hline & & & & Airblast & Above-row \\
\hline \multicolumn{6}{|c|}{ Anthracnose } \\
\hline 1995 & Incubation & 1 & Top & $8.3 \mathrm{~A}^{\mathrm{z}}$ & $3.4 \mathrm{~B}$ \\
\hline 1995 & Incubation & 1 & bottom & $11.7 \mathrm{a}$ & $4.4 \mathrm{~b}$ \\
\hline 1998 & Storage (14d) & 2 & Top & $12.0 \mathrm{a}$ & $6.8 \mathrm{~b}$ \\
\hline \multicolumn{6}{|c|}{ Alternaria } \\
\hline 1998 & Storage (7d) & 2 & bottom & $1.6 \mathrm{a}$ & $0.9 \mathrm{~b}$ \\
\hline \multicolumn{6}{|c|}{ Botrytis } \\
\hline 1998 & Incubation & 2 & Top & $0.4 \mathrm{a}$ & $0.8 \mathrm{~b}$ \\
\hline
\end{tabular}

${ }^{2}$ Mean separation within rows by LSD, $P \leq 0.05$ (lower-case letters) or $\leq 0.01$ (upper-case letters).

fungicide rates would have been useful, but were not feasible given the field limitations. The level of control provided by either spray treatment is not known, since a nonsprayed control could not be included. However, these results indicate that the above-row sprayer provided the same or greater control of fruit rots than an airblast sprayer delivering onethird more fungicide.

The spray deposition patterns of these sprayers were studied in the same pruning plots in a companion study (Van Ee et al., 2000). The above-row sprayer often provided better coverage on card targets placed in the top of the canopy, whereas coverage in the bottom of bushes was often better with the airblast sprayer. Fruit rot levels in the tops and the bottoms of the bushes in the current study did not generally reflect these deposition patterns.

The incubation procedure appeared to be a more rigorous test for the presence of fungi than simulations of commercial handling conditions. Berries from the first and second harvests in 1997 and the second harvest in 1998 were subjected to both tests. Mean rot levels across all treatments and positions in the canopy were higher for incubation tests $(33.8 \%$ anthracnose, $7.0 \%$ Alternaria, 27.2\% Botrytis) than following short-term $(6.2 \%$ anthracnose, $1.4 \%$ Alternaria, $0.4 \%$ Botrytis) or longerterm $(5.2 \%$ anthracnose, $0.9 \%$ Alternaria, $0.5 \%$ Botrytis) commercial handling simulations. Rot levels could have been increased by prolonging incubation at $19^{\circ} \mathrm{C}$. The duration of the commercial storage period did not consistently affect rot levels, but the short- and longterm storage regimes differed only in the length of time at $2{ }^{\circ} \mathrm{C}$. In these tests, rotting may have resulted from latent infections or infections occurring during incubation or storage. Colletotrichum acutatum and Alternaria sp. may infect blueberries after harvest, if the surfaces of sorting equipment are wet and contaminated with spores (Cline, 1996).

In conclusion, this study demonstrated that the above-row sprayer could allow growers to reduce recommended fungicide rates by onethird without increasing the incidence of fruit rots. An added advantage of this sprayer is a greater swath width (four rows) so that more acreage can be treated in less time, providing greater flexibility when conditions are optimal. From a commercial standpoint, the pruning treatments yielded conflicting results. Pruning often reduced anthracnose rot, but also reduced yields in two seasons. Note again that the long-term effects of these pruning treatments could not be determined as the study only lasted 3 years and was confounded by the inadvertent pruning of all plots in 1998 .

\section{Literature Cited}

Bristow, P.R. and G.E. Windom. 1998. Epidemiology of Alternaria fruit rot in the Pacific Northwest, p. 276-279. In: Proc. 8th N. Amer. Blueberry Res. Ext. Work. Conf., Wilmington, N.C., 27-29 May.

Caruso, F.L. and D.C. Ramsdell. 1995. Compendium of blueberry and cranberry diseases. APS Press, Amer. Phytopathol. Soc., St. Paul, Minn.

Ceponis, M.J. and R.A. Cappellini. 1978. Relationship of chemical application time to postharvest disease control in blueberries. Plant Dis. Rptr. 62:1005-1007.

Cline, W.O. 1996. Postharvest infection of highbush blueberries following contact with infested surfaces. HortScience 31:981-983.

Cooley, D.R., J.W. Gamble, and W.R. Autio. 1997. Summer pruning as a method for reducing flyspeck disease on apple fruit. Plant Dis. 81:11231126.

Hartung, J.S., C.L. Burton, and D.C. Ramsdell. 1981. Epidemiological studies of blueberry anthracnose disease caused by Colletotrichum gloeosporioides. Phytopathology 71:449-453.

Johnson, J.W., J. Hull, and A.L. Jones. 1995. Fruit spraying calendar. Michigan State Univ. Ext. Bul. E-154.

Ramsdell, D.C. 1989. Blueberry diseases in Michigan. Michigan State Univ. Ext. Bul. E-1731.

Ramsdell, D.C. 1992. Nematode and disease management, p. 76-94. In: M.P. Pritts and J.F. Hancock (eds.). Highbush blueberry production guide. Northeast Reg. Agr. Eng. Serv., Cornell Univ., Ithaca, N.Y.

Siefker, J.A. and J.F. Hancock. 1987. Pruning effects on productivity and vegetative growth in the highbush blueberry. HortScience 22:210-211.

U.S. Dept. of Agriculture, National Agricultural Statistics Service. 1998. Agricultural chemical usage 1997 fruits summary. Bul. Agr. Ch. 1(98), Washington, D.C.

Van Ee, G., R. Ledebuhr, E. Hanson, J. Hancock, and D.C. Ramsdell. 2000. Canopy development and spray deposition in highbush blueberry. HortTechnology 10:353-359. 